\title{
Hypnosis is a Surgical Pain Intervention: A Systematic Review
}

\author{
$1^{\text {st }}$ Sidik Awaludin \\ School of Nursing \\ Jenderal Soedirman \\ University \\ Purwokerto, Indonesia \\ abifayza@yahoo.co.id
}

\author{
$2^{\text {nd }}$ Elly Nurachmah \\ Doctorate Nursing Program \\ Indonesia University \\ Depok, Indonesia \\ ellynur08@yahoo.co.id
}

\author{
$3^{\text {th }}$ Dwi Novitasari \\ School of Nursing \\ Harapan Bangsa University \\ Purwokerto, Indonesia \\ dwinovitasari@uhb.ac.id
}

Surgery is a medical procedure that can cause perioperative pain. Pain in the perioperative phase that received by the patient can cause various complications. Hypnosis is a part of complementary and alternative therapies that are able to cope with pain. The purpose of the review is to perform a systematic review of the literature. Hypnosis is a part of complementary and alternative therapies that are able to cope with pain in surgery. A comprehensive article search through EBSCO, PROQUEST, and Scopus, the original article was sought in the period of publication between 1999 and 2019. The original articles reported on the effectiveness of hypnosis with surgical patient inclusion criteria. A total of 1994 studies have been identified in the literature search. However, only 27 studies were eligible for analysis in this study. The instruments used were visual analogue scale and numeric rating scale questionnaire were used to identify the level of pain in the study. The outcome revealed that hypnosis can decrease level of pain in each perioperative phase significantly. Further research needs to be done to add strong evidence about the use of hypnosis for perioperative pain management.

\section{Keywords: hypnosis, pain, surgery}

\section{INTRODUCTION}

Surgery is an action to overcome health problems that occur in patients, but it can cause psychological stress, severe pain, and suffering [1]. Perioperative pain that is not intervened will cause new problems that are detrimental. Recently, various nonpharmacological therapies have been found to treat pain such as hypnosis. Hypnosis is a technique that can change phenomenological aspects, relieve pain, reduce anxiety and depression, increase comfort, and can be used as analgesics during pre and postsurgery. [2-4]. Hypnosis can be used to treat pain at the perioperative stage in various types of surgery [5], such as cardiac surgery [2], cataract surgery [4], liposuction surgery [3], endocrine surgery [6], breast surgery [7], musculoskeletal surgery $[8]$ and so on.

Hypnosis is a therapy without side effects for patients. The initial stage of hypnosis therapy is most often done by giving an introduction to action by telling the patient about an imaginative experience by asking the patient to imagine something pleasant. The next stage is induction, which is an initial suggestion which is expanded to use imagination and further elaboration of the introduction. Hypnosis are used to support and evaluate suggestion responses. When the patient is hypnotized, the patient will be guided by therapist to respond the suggestions for changes in subjective experiences and changes in perception, sensation, emotions, thoughts, or behavior. Hypnosis can also be done independently by the patient, this is known selfhypnotized. [9].

The aim of this review was to perform a systematic review of the literature. The researcher identified and looked for the relationship of trends, topics and perceptions related to hypnosis as pain interventions. The main purpose of this review was to incorporate peer review research to meet the needs of patients in coping with surgical pain.

This review used extraction and synthesis methods applied to the literature sought and selected for review, explained in the next section. The results of this review provided classifications in terms of performance, composition, improvisation, and analysis. The discussion process discusses the invention and limitations. The last step explains the implications and recommendations for further research.

\section{METHOD}

This review referred to the Item Reporting Options for Systematic Review and Meta Analytic (PRISMA) guidelines. This systematic review was carried out with the following stages; The First, an electronic literature search was conducted according to the research questions and establish inclusion criteria. Second step was the research paper that meets the inclusion criteria selected. The third step was the data from the selected papers extracted and, the fourth stage carried out a qualitative and semi-quantitative analysis. The researcher discussed the searching and data synthesis strategy in the following section.

\section{Searching techniques and selection criteria}

The following systematic electronic database searches were published between 1999 and 2019. Searches were carried out through Pro-quest, EBSCO, and Scopus, using the keywords "hypnosis", "sick", "surgery". The search process was limited to English. The clear and detail method can be seen in table 1 .

Table 1 Database Search

\begin{tabular}{ccccc}
\hline $\begin{array}{c}\text { Search } \\
\text { Date }\end{array}$ & Data source & Years & $\begin{array}{c}\text { Number } \\
\text { of articles }\end{array}$ & Total \\
\hline $22-07-2019$ & PROQUEST & $\begin{array}{l}1999- \\
2019\end{array}$ & 1683 & \multirow{2}{*}{1994} \\
\hline $22-07-2019$ & EBSCO & $\begin{array}{l}1999- \\
2019\end{array}$ & 55 & \\
\hline $22-07-2019$ & Scopus & $\begin{array}{l}1999- \\
2019\end{array}$ & 256 & \\
& & & \\
\hline
\end{tabular}

Extraction and Synthesis of Data 
The author, consisting of three individuals, extracted data from each study and every time a difference was found, it was resolved by discussion. Data Extraction and Synthesis can be seen in figure 1.

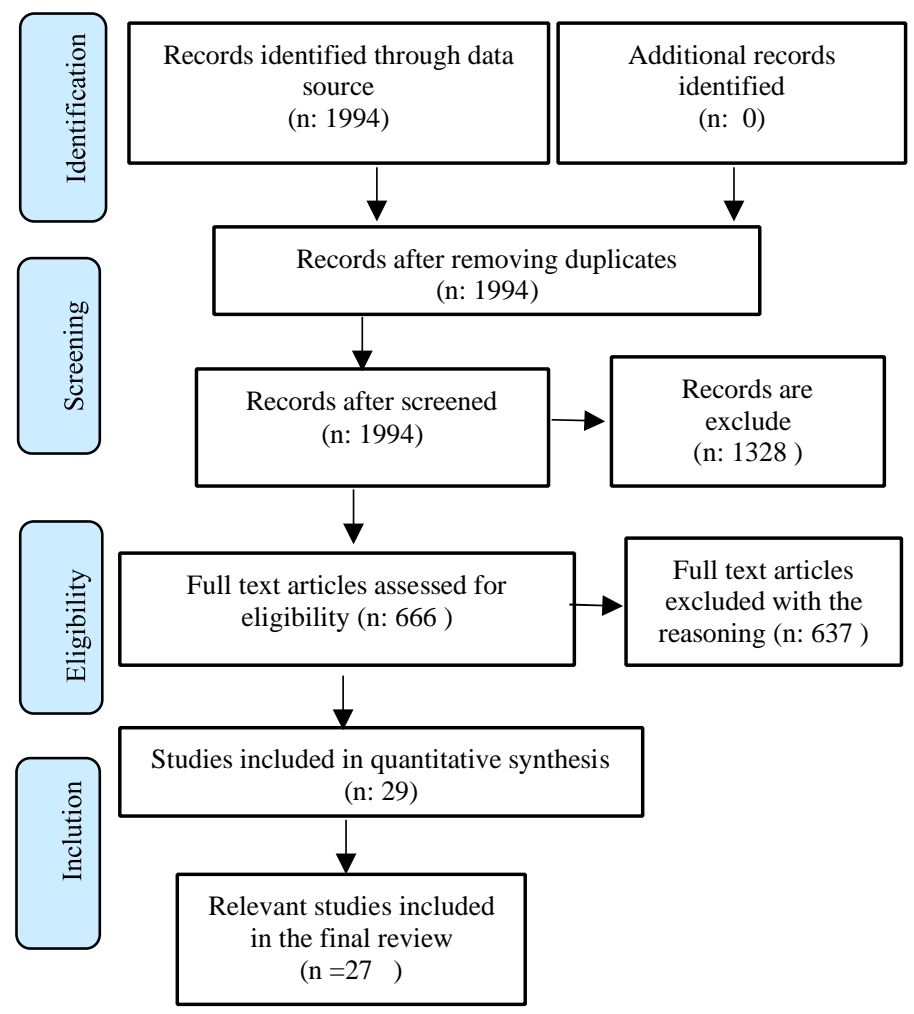

Fig. 1 Flow of diagram of study selection process

\section{RESULTS AND DISCUSSION}

The number of search results found was 1994 articles. All data were relevant according to the inclusion criteria, so the results remained in 1994 articles. Figure 1 explains the process of finding the PRISMA method. After observing the inclusion criteria, only 27 articles were met the inclusion criteria which would be further analyzed. The frequency characteristics can be seen in Table 1. During the period 1999-2019, 27 scientific publications on hypnosis were used as interventions to treat surgical pain. Methodology, design, type of intervention, measurement method and sample can be seen in table. 2

The most used design in this review was RCT (5 articles), then prospective studies (5 articles), observational studies with 3 articles each, other designs found were true experiments, retrospectives, mixed methods, comprehensive reviews, comprehensive historical studies and control with 1 article each. The assessment instruments used mostly use VAS, while the timing of hypnosis intervention was mostly done before surgery, and it was followed by postoperative, perioperative, preoperative, and postoperative. The duration of hypnosis intervention was between 5 to 89 minutes with an average of 20 minutes. The results of all article reviewed indicated that hypnosis could significantly be used as an intervention for surgical pain.

The article reviewed shows that there is evidence that hypnosis is a surgical pain intervention. A comprehensive and systematic review of our research study found 27 articles published 1999 - 2019.

Pain and anxiety are the most common side effects of surgery [10]. The use of hypnosis in clinical practice has long been used. There are beneficial effects of hypnosis in patients undergoing major operations which are explained from a variety of relevant literature. [6]. Hypnosis has been practiced by surgeons when operating, patients are observed from the beginning to the end of the procedure. The results of this observations showed that the patients were free from pain during the action. [3]. Hypnosis can affect patient perception and behavior in two ways, namely the use of suggestibility and hypnotic trance. Trance is a state similar to being unconscious, which is different from normal sleep, but is very conscious, focused, and has a high degree of suggestibility, Andrew and Welbury (1996) conducted a study of 20 children who underwent hypnosis and anesthesia, the results reported 16 children have experienced decreased in pain perception [11-13]. The use of hypnosis in eye surgery showed that it was successful in reducing pain. In total, patients who performed eye surgery in the intervention group showed a higher reduction in pain compared to the control group using usual topical anesthesia. Although pain is still sometimes felt and is different from each individual, it is influenced by pain sensitivity. Overall, many patients in the hypnosis group experienced decreased pain and lower anxiety. An additional positive effect is obtained by the patient being increased in cooperation during the surgical procedure. [4].

Hypnosis as analgesia has also been implemented in other operations such as thyroid removal, termination of pregnancy, removal of skin tumor or inguinal repair. The results of the implementation showed that hypnosis produced significant positive effects in reducing stress, pain, drug consumption, physiological parameters, and duration of surgery [7]. In patients undergoing laparoscopic cholecystectomy, hypnosis may be recommended for use in the preoperative period to be an adjunct therapy of usual care in reducing pain and taking sedatives. [1]. 
Table 2. Included Studies

\begin{tabular}{|c|c|c|c|c|c|c|}
\hline No & Author, Years & Sample, Age & $\begin{array}{c}\text { Design, } \\
\text { Assessment tool }\end{array}$ & Type surgery & Interventions & Method and Time for Measurement \\
\hline 1 & [11] & $\mathrm{n}: 24$, age $18-30 \mathrm{yr}$ & $\begin{array}{l}\text { Case control study, } \\
\text { Visual Analogue } \\
\text { Scale (VAS) }\end{array}$ & $\begin{array}{l}\text { Extraction of } \\
\text { mandibular, maxillary } \\
\text { molars surgery }\end{array}$ & Preoperative & $\begin{array}{l}\text { Intensity of pain assessment at } 5,12,24 \text {, and } \\
48 \text { hours postoperative intervals }\end{array}$ \\
\hline 2 & [12] & n: 13 studies & $\begin{array}{l}\text { A comprehensive } \\
\text { methodological } \\
\text { review, PsycINFO } \\
\text { and PubMed } \\
\text { [3]databases }\end{array}$ & $\begin{array}{l}\text { Lumbar puncture, } \\
\text { Tonsillectomy, Nuss } \\
\text { procedure }\end{array}$ & During the procedure & $\begin{array}{l}\text { Through six groups according to the nature } \\
\text { and condition of the treatment being } \\
\text { compared. }\end{array}$ \\
\hline 3 & [2] & $\begin{array}{l}\text { n: } 44, \text { mean age } \\
54 \& 55 \mathrm{yr}\end{array}$ & $\begin{array}{l}\text { RCT, Visual analog } \\
\text { scale (VAS) }\end{array}$ & CABG surgery & Preoperative & $\begin{array}{l}\text { Patients were divided into interventional and } \\
\text { control group. Pain were evaluated on } 0 \text { th, } \\
1 \text { st, } 2 \text { nd, } 4 \text { th, } 6 \text { th }, 8 \text { th }, 10_{\mathrm{th}}, 12_{\mathrm{th}} \text {, and } 24_{\mathrm{th}} \text { hours } \\
\text { after surgery }\end{array}$ \\
\hline 4 & [10] & $\begin{array}{l}\mathrm{n}: 300, \text { mean age } \\
58 \& 59,5\end{array}$ & $\begin{array}{l}\text { Observational } \\
\text { nonrandomized } \\
\text { study, none }\end{array}$ & Breast surgery & Postoperative & $\begin{array}{l}150 \text { patients underwent breast surgery while } \\
\text { on general anesthesia, and } 150 \text { patients } \\
\text { underwent the same surgical procedures } \\
\text { while on hypnosis sedation, not explained } \\
\text { measurement time }\end{array}$ \\
\hline 5 & [3] & none & Observational & Liposuction surgery & Preoperative & $\begin{array}{l}\text { The surgeon used self-hypnosis. The } \\
\text { dialogue was transferred to an audio cassette } \\
\text { tape approximately } 20 \text { minutes in length and } \\
\text { listened to for five evenings prior to surgery, } \\
\text { not explained measurement time. }\end{array}$ \\
\hline 6 & [4] & $\begin{array}{l}\text { n: 111, aged 50-85 } \\
\text { yr }\end{array}$ & $\begin{array}{l}\text { True experimental, } \\
\text { Visual analog scale } \\
\quad \text { (VAS) }\end{array}$ & Cataract surgery & Intraoperative & $\begin{array}{l}\text { After describing the hypnosis procedure, the } \\
\text { hypnotherapist initiated a } 10 \text { to } 15 \text { minute } \\
\text { short hypnosis using a technique } \\
\text { described by Erickson, } \\
\text { after the hypnosis session, the patient's } \\
\text { anxiety for the forth coming surgery was } \\
\text { evaluated }\end{array}$ \\
\hline 7 & [14] & n: 40, none & $\begin{array}{c}\text { Prospective } \\
\text { randomized study, } \\
\text { Visual analog scale } \\
\text { (VAS) }\end{array}$ & $\begin{array}{l}\text { Cervical endocrine } \\
\text { surgery }\end{array}$ & Postoperative & $\begin{array}{l}\text { The two groups are compared, not explained } \\
\text { measurement time }\end{array}$ \\
\hline
\end{tabular}




\begin{tabular}{|c|c|c|c|c|c|c|}
\hline No & Author, Years & Sample, Age & $\begin{array}{c}\text { Design, } \\
\text { Assessment tool }\end{array}$ & Type surgery & Interventions & Method and Time for Measurement \\
\hline 8 & [6] & $\begin{array}{c}\text { n: } 339, \text { mean age } \\
42 \& 63,7 \mathrm{yr}\end{array}$ & $\begin{array}{c}\text { Retrospective study, } \\
\text { Visual analog scale } \\
\text { (VAS) }\end{array}$ & Endocrine surgery & $\begin{array}{c}\text { Intraoperative and } \\
\text { postoperative }\end{array}$ & $\begin{array}{l}\text { Patients were divided into interventional } \\
\text { and control group Postoperative pain and } \\
\text { patient satisfaction were assessed using a } \\
10 \mathrm{~cm} \text { visual analogue scale }\end{array}$ \\
\hline 9 & [15] & $\begin{array}{c}\mathrm{n}: 22, \text { mean age } \\
25,6 \mathrm{yr}\end{array}$ & $\begin{array}{c}\text { Prospective } \\
\text { observational } \\
\text { investigation, } \\
\text { Visual analog scale } \\
\text { (VAS) }\end{array}$ & Open septorhinoplasty & Preoperative & $\begin{array}{l}\text { Patients were divided into interventional } \\
\text { and control group. The first two were } \\
\text { administered } 3 \text { days and } 1 \text { day prior to } \\
\text { surgery, respectively, and the last session } \\
\text { was administered in the hospital the day of } \\
\text { surgery. Hypnosis induction was given by } \\
\text { the same anesthesiologis. The first two } \\
\text { hypnosis sessions were } 40 \text { min duration, and } \\
\text { the last one was } 20 \text { min }\end{array}$ \\
\hline 10 & [13] & n: 86 , age $18-65$ yr & $\begin{array}{c}\text { A prospective } \\
\text { single-blinded } \\
\text { study, Visual } \\
\text { analog scale (VAS) }\end{array}$ & $\begin{array}{c}\text { Transesophageal } \\
\text { echocardiography } \\
\text { (TEE) }\end{array}$ & Preintervention & $\begin{array}{l}\text { A first hypnotic induction was carried out } \\
\text { the day before the procedure, the second } \\
\text { hypnosis induction was done in a separate } \\
\text { room } 15 \text { minutes before the } \\
\text { intervention }\end{array}$ \\
\hline 11 & [7] & n: 1 , age $58 \mathrm{yr}$ & A case report, none & Breast cancer surgery & Perioperative & $\begin{array}{l}\text { During the consultation, the patient } \\
\text { underwent her first hypnosis and all details } \\
\text { of the proceedings } \\
\text { (induction, breathing focalization, notion of } \\
\text { "safe place"...) were given, The hypnotist } \\
\text { used permissive suggestions to the patient to } \\
\text { produce relaxation and peace and for } \\
\text { alterations in perception, sensation, and } \\
\text { emotion throughout the procedure. The } \\
\text { surgery and hypnosis lasted } 52 \text { and } \\
89 \text { minutes, respectively }\end{array}$ \\
\hline 12 & {$[8]$} & n: 12 , age $21-49$ yr & $\begin{array}{c}\text { A randomized } \\
\text { control pilot study, } \\
\text { none }\end{array}$ & Bone fracture & Postoperative & All the subject received for 6 weeks \\
\hline 13 & {$[16]$} & n: unclear & $\begin{array}{l}\text { Historical\& } \\
\text { contemporer }\end{array}$ & Major surgeries & Perioperative & $\begin{array}{l}\text { Hypnosis was given by hypnotist } 530 \\
\text { minutes }\end{array}$ \\
\hline
\end{tabular}




\begin{tabular}{|c|c|c|c|c|c|c|}
\hline No & Author, Years & Sample, Age & $\begin{array}{c}\text { Design, } \\
\text { Assessment tool }\end{array}$ & Type surgery & Interventions & Method and Time for Measurement \\
\hline & & & perspectives, none & & & \\
\hline 14 & [9] & $\begin{array}{l}\text { n: } 64, \text { mean age } \\
61,8 \& 63,5 \mathrm{yr}\end{array}$ & $\begin{array}{l}\text { Prospective study, } \\
\text { Visual analog scale } \\
\text { (VAS) }\end{array}$ & $\begin{array}{l}\text { TRUS-guided prostate } \\
\text { needle biopsy }\end{array}$ & Preoperative & $\begin{array}{l}\text { Patients were divided into interventional and } \\
\text { control group. Assessment of pain after } 10 \\
\text { min intervention. After surgery, both } \\
\text { hypnosis intervention and control groups } \\
\text { were given the measures again. }\end{array}$ \\
\hline 15 & [1] & $\begin{array}{l}\text { n: } 120, \text { mean age } \\
43,10 \& 3,15 \mathrm{yr}\end{array}$ & $\begin{array}{c}\text { True experimental, } \\
\text { Visual analog scale } \\
\text { (VAS) }\end{array}$ & $\begin{array}{l}\text { Laparoscopic } \\
\text { cholecystectomy }\end{array}$ & Postoperative & $\begin{array}{l}\text { The pain assessment on } 2,6,12 \text {, and } 24 \text { hours } \\
\text { postsurgery. }\end{array}$ \\
\hline 16 & [17] & n: 20 , age $30-79$ yr & $\begin{array}{l}\text { A mixed method, } \\
\text { none }\end{array}$ & Breast cancer surgery & Preoperative & $\begin{array}{l}\text { The hypnosis intervention consisted of a } 15 \\
\text { minute, not explained measurement time }\end{array}$ \\
\hline 17 & [5] & n: 91 , age $18-25$ yr & $\begin{array}{l}\text { A randomized blind } \\
\text { control study, } \\
\text { Visual analogue } \\
\text { scale, containing a } \\
\text { numeric rating scale }\end{array}$ & Molar extraction & Intraoperative & $\begin{array}{l}\text { The patient was called by phone on the first } \\
\text { postoperative day and asked to report where } \\
\text { they rated their postoperative pain on the } \\
\text { VAS. }\end{array}$ \\
\hline 18 & [18] & n: 350, age $\geq 18$ yr & $\begin{array}{c}\text { Randomized } \\
\text { Clinical Trial, none }\end{array}$ & $\begin{array}{l}\text { First-trimester surgical } \\
\text { abortion }\end{array}$ & Preoperative & $\begin{array}{l}\text { Patients were divided into interventional and } \\
\text { control group. The interventional group } \\
\text { received a } 20 \text { minute hypnotic intervention } \\
\text { before the surgical abortion and throughout } \\
\text { the procedure. } \\
\text { Suggestions are repeated using the same } \\
\text { words as during the } 20 \text { minute }\end{array}$ \\
\hline 19 & [19] & n: 350, age $\geq 18$ yr & $\begin{array}{c}\text { Randomized } \\
\text { Clinical Trial, none }\end{array}$ & Surgical abortion & $\begin{array}{l}\text { Preoperative and } \\
\text { Intraoperative }\end{array}$ & $\begin{array}{l}\text { Patients were divided into interventional and } \\
\text { control group. In the Intervention group } 20 \\
\text { min before and throughout the surgical } \\
\text { procedure. The Control group, each woman } \\
\text { was accompanied by a relative or friend for } \\
20 \text { min before the surgical procedure and by } \\
\text { a nurse. }\end{array}$ \\
\hline
\end{tabular}




\begin{tabular}{|c|c|c|c|c|c|c|}
\hline No & Author, Years & Sample, Age & $\begin{array}{c}\text { Design, } \\
\text { Assessment tool }\end{array}$ & Type surgery & Interventions & Method and Time for Measurement \\
\hline 20 & [20] & $\mathrm{n}: 1$, age $4 \mathrm{yr}$ & $\begin{array}{l}\text { Case report, Visual } \\
\text { analogue scale } \\
\text { (VAS) }\end{array}$ & Oral and maxillofacial & $\begin{array}{l}\text { Intraoperative and } \\
\text { postoperative }\end{array}$ & $\begin{array}{l}\text { An hypnosis session was held to control } \\
\text { anxiety, fear, and pain during and after the } \\
\text { procedure. Hypnosis was induced prior to } \\
\text { the }\end{array}$ \\
\hline & & & & & & $\begin{array}{l}\text { surgical procedure. The deepening of the } \\
\text { hypnotic trance occurred for } 5 \text { min, with } \\
\text { commands for a imagine visual image, } \\
\text { wellness tips, peace, and tranquility. Then, a } \\
\text { suggestion that involved the hypnotic } \\
\text { anesthesia and hemostasis was made. After } \\
\text { the surgical procedure and } 1 \text { week later, we } \\
\text { used the visual analog scale (VAS) to } \\
\text { measure the patient's pain level }\end{array}$ \\
\hline 21 & [21] & $\begin{array}{c}\mathrm{n}: 200, \text { mean age } \\
48,5 \mathrm{yr}\end{array}$ & $\begin{array}{l}\text { Unclear, Visual } \\
\text { analogue scale }\end{array}$ & Breast cancer surgical & Postoperative & The hypnosis is done for 15 minutes \\
\hline 22 & [22] & n: - & Review, none & Breast cancer surgery & Perioperative & $\begin{array}{l}\text { The effect of clinical hypnosis performed } \\
\text { during the perioperative period }\end{array}$ \\
\hline 23 & [23] & n: - & Review, none & $\begin{array}{c}\text { The sole anaesthetic for } \\
\text { surgical }\end{array}$ & Perioperative & $\begin{array}{l}\text { The effect hypnosis performed during th } \\
\text { perioperative }\end{array}$ \\
\hline 24 & [24] & $\begin{array}{c}\text { n: } 103 \text {, median age } 60 \\
\& 54 \mathrm{yr}\end{array}$ & $\begin{array}{c}\text { An observational and } \\
\text { prospective study, }\end{array}$ & Inguinal hernia repair & Preoperative & $\begin{array}{l}\text { The hypnosis is done when patient is setting } \\
\text { in operating room on the operating table. }\end{array}$ \\
\hline 25 & [25] & n: unclear & Review & $\begin{array}{c}\text { Radical breast } \\
\text { mastectomy, pelvic } \\
\text { exenteration, } \\
\text { colorectal and prostate } \\
\text { surgery, as well as other } \\
\text { genital surgeries }\end{array}$ & Postoperative & $\begin{array}{l}\text { As a consequence, counsellors and } \\
\text { hypnotherapists can assist clients towards life } \\
\text { enhancing healthy emotional states that can } \\
\text { reduce pain, as well as increase confidence, } \\
\text { self-esteem and selfworth. }\end{array}$ \\
\hline
\end{tabular}




\begin{tabular}{|c|c|c|c|c|c|c|}
\hline No & Author, Years & Sample, Age & $\begin{array}{c}\text { Design, } \\
\text { Assessment tool }\end{array}$ & Type surgery & Interventions & Method and Time for Measurement \\
\hline 26 & {$[26]$} & n: 75, age 35-70 yr & $\begin{array}{c}\text { A randomized } \\
\text { experimental } \\
\text { design, Visual } \\
\text { analogue scale } \\
\text { (VAS) }\end{array}$ & Breast biopsy & $\begin{array}{l}\text { Preoperative and postoperative } \\
\text { Patients were divided into intervention and } \\
\text { control group The intervention group listened } \\
\text { to a 17 minute recorded script with hypnotic } \\
\text { suggestions. The control group received } \\
\text { standard care, remaining in the waiting room } \\
\text { for 17 minutes. }\end{array}$ \\
\hline 27 & {$[27]$} & n: - & Review & Various surgery & unclear & Did not explained measurement time \\
\hline
\end{tabular}




\section{CONCLUSION AND RECOMMENDATION}

The implementation of hypnosis in surgery has long been used. Hypnosis can eliminate negative feelings, emotional distress, pain, anxiety, and consumption of analgesic drugs. Moreover, it can increase independence, cooperation, and self-confidence.. Hypnosis can be used in the perioperative period.

\section{RECOMMENDATION}

Nurses, doctors, and anesthetists as perioperative staff must have the knowledge and ability to apply hypnosis. Based on the results of this review, hypnosis has the greatest benefit in the preoperative stage. Therefore, future research needs to look at the effects of hypnosis in the intraoperative and postoperative periods. Much research is still needed to provide strong evidence of the use of hypnosis in the perioperative stage.

\section{LIMITATION}

This review is limited only in the year of 1999-2019 and English language, so it may give language and publications bias.

\section{FINANCIAL SPONSOR}

The author received no financial sponsor for the review, authorship and publication of this article.

\section{CONFLICT OF INTEREST}

No conflict of interest

\section{ACKNOWLEDGMENT}

We are very grateful to all the original article authors who were useful for writing this review.

\section{REFERENCES}

[1] M. Joudi, M. Fathi, A. Izanloo, O. Montazeri, and A. Jangjoo, "An Evaluation of the Effect of Hypnosis on Postoperative Analgesia following Laparoscopic Cholecystectomy," The International Journal of Clinical And Experimental Hypnosis, vol. 64, no. 3, pp. 365372, 2016.

[2] A. Akgul, B. Guner, M. Çırak, D. Çelik, O. Hergünsel, and S. Bedirhan, "The Beneficial Effect of Hypnosis in Elective Cardiac Surgery: A Preliminary Study," Thoracic and Cardiovascular Surgeon, Article vol. 64, no. 7, pp. 581-588, 2016.

[3] S. A. Botta, "Self-Hypnosis as Anesthesia for Liposuction Surgery," American Journal of Clinical Hypnosis, Article vol. 41, no. 4, pp. 299301, 1999.
[4] X. Chen et al., "Hypnosis intervention for the management of pain perception during cataract surgery," (in English), Journal of Pain Research, vol. 11, pp. 1921-1926, 2018

[5] E. F. Mackey, "Effects of hypnosis as an adjunct to intravenous sedation for third molar extraction: a randomized, blind, controlled study," International Journal of Clinical \& Experimental Hypnosis, vol. 58, no. 1, pp. 21-38, 2010.

[6] T. Defechereux, M. Meurisse, E. Hamoir, L. Gollogly, J. Joris, and M. E. Faymonville, "Hypnoanesthesia for endocrine cervical surgery: a statement of practice," Journal Of Alternative And Complementary Medicine (New York, N.Y.), vol. 5, no. 6, pp. 509-520, 1999.

[7] R. Fuzier, S. Achelous, G. Salvignol, and E. Jouve, "Hypnosis and Axillary Compartment Block for Breast Cancer Surgery: A Case Report," A \&amp; A case reports, Article vol. 9, no. 3 , pp. 81-83, 2017.

[8] C. S. Ginandes and D. I. Rosenthal, "Using hypnosis to accelerate the healing of bone fractures: A randomized controlled pilot study," (in English), Alternative Therapies in Health and Medicine, vol. 5, no. 2, pp. 67-75,

[9] F. Hizli et al., "The effects of hypnotherapy during transrectal ultrasound-guided prostate needle biopsy for pain and anxiety," (in English), International Urology and Nephrology, vol. 47, no. 11, pp. 1773-1777, 2015

[10] M. Berlière et al., "The advantages of hypnosis intervention on breast cancer surgery and adjuvant therapy," Breast, Article vol. 37, pp. 114-118, 2018.

[11] S. K. Abdeshahi, M. A. Hashemipour, V. Mesgarzadeh, A. Shahidi Payam, and A. Halaj Monfared, "Effect of hypnosis on induction of local anaesthesia, pain perception, control of haemorrhage and anxiety during extraction of third molars: A case-control study," Journal of Cranio-Maxillofacial Surgery, vol. 41, no. 4, pp. 310-315, 2013.

[12] M. C. Accardi and L. S. Milling, "The effectiveness of hypnosis for reducing procedure-related pain in children and adolescents: a comprehensive methodological review," (in English), Journal of Behavioral Medicine, vol. 32, no. 4, pp. 328-39, Aug 2009

[13] G. Eren et al., "Hypnosis for sedation in transesophageal echocardiography: a comparison with midazolam," (in English), Annals of Saudi Medicine, vol. 35, no. 1, pp. 58-63, Jan/Feb

[14] T. Defechereux et al., "Hypnosedation: A new anesthesia technique for cervical endocrine surgery. A prospective randomized study," 
Annales de Chirurgie, Article vol. 125, no. 6, pp. 539-546, 2000.

[15] S. Efsun Ozgunay, S. Ozmen, D. Karasu, C. Yilmaz, and I. Taymur, "The Effect of Hypnosis on Intraoperative Hemorrhage and Postoperative Pain in Rhinoplasty," International Journal of Clinical and Experimental Hypnosis, Article vol. 67, no. 3, pp. 262-277, 2019.

[16] D. C. P. A. Hammond, "Hypnosis as Sole Anesthesia for Major Surgeries: Historical \& Contemporary Perspectives," (in English), American Journal of Clinical Hypnosis, vol. 51,

[17] M. W. Lew, K. Kravits, C. Garberoglio, and A. C. Williams, "Use of preoperative hypnosis to reduce postoperative pain and anesthesia-related side effects," The International Journal of Clinical And Experimental Hypnosis, vol. 59, no. 4, pp. 406-423, 2011.

[18] I. Marc, P. Rainville, and S. Dodin, "Hypnotic induction and therapeutic suggestions in firsttrimester pregnancy termination," International Journal of Clinical and Experimental Hypnosis, Article vol. 56, no. 2, pp. 214-228, 2008.

[19] I. Marc et al., "Women's new hampshire views regarding hypnosis for the control of surgical pain in the context of a randomized clinical trial," Journal of Women's Health, Article vol. 18, no. 9, pp. 1441-1447, 2009.

[20] G. Montenegro, L. Alves, A. L. Zaninotto, D. P. Falcão, and R. F. B. de Amorim, "Hypnosis as a Valuable Tool for Surgical Procedures in the Oral and Maxillofacial Area," American Journal of Clinical Hypnosis, Article vol. 59, no. 4, pp. 414421, 2017.

[21] G. H. Montgomery, M. N. Hallquist, J. B. Schnur, D. David, J. H. Silverstein, and D. H. Bovbjerg, "Mediators of a brief hypnosis intervention to control side effects in breast surgery patients: Response expectancies and emotional distress," (in English), Journal of Consulting and Clinical Psychology, vol. 78, no. 1, pp. 80-88, Feb 2010

[22] A. Potié, F. Roelants, A. Pospiech, M. Momeni, and C. Watremez, "Hypnosis in the Perioperative Management of Breast Cancer Surgery: Clinical

Benefits and Potential Implications," Anesthesiology Research and Practice, Review vol. 2016, 2016, Art. no. 2942416.

[23] D. Rogerson, "The Use of Hypnosis in Surgery and Anesthesiology: Psychological Preparation of the Surgical Patient," (in English), Contemporary Hypnosis, vol. 19 , no. 1, p. 44,2002

[24] B. Romain, M. Rodriguez, F. Story, J. B. Delhorme, C. Brigand, and S. Rohr, "Outcomes of hypnosis combined with local anesthesia during inguinal repair: a pilot study," Hernia: The Journal Of Hernias And Abdominal Wall Surgery, vol. 21, no. 1, pp. 59-63, 2017.

[25] E. A. D. C. H. P. M. Stephan, "Hypnotherapy for Pain Management, Self Esteem, and Reestablishing Sexuality and Intimacy After Surgery," (in English), Australian Journal of Clinical Hypnotherapy and Hypnosis, vol. 36, no. 2, pp. 33-45,48,

[26] A. Téllez, T. Sánchez-Jáuregui, D. M. JuárezGarcía, and M. García-Solís, "Breast Biopsy: The Effects of Hypnosis and Music," The International Journal of Clinical And Experimental Hypnosis, vol. 64, no. 4, pp. 456469, 2016.

[27] S. M. Valente, "Hypnosis for pain management," Journal Of Psychosocial Nursing And Mental Health Services, vol. 44, no. 2, pp. 22-30, 2006. 